\title{
Determinan Daya Beli Masyarakat Indonesia Selama Pandemi Covid-19 Tahun 2020
}

\author{
(Determinants of Indonesian People's Purchasing Power During the Covid-19 Pandemic in 2020)
}

\author{
Dimas Prayogo ${ }^{1^{*}}$, Sukim $^{2}$ \\ ${ }^{1,2}$ Politeknik Statistika STIS \\ Jalan Otto Iskandardinata No. 64C, Jakarta Timur, 13330, Indonesia \\ E-mail: 211709631@stis.ac.id
}

\begin{abstract}
ABSTRAK
Pandemi Covid-19 yang terjadi di Indonesia membuat pemerintah mengeluarkan kebijakan pembatasan sosial yang memberikan dampak terhadap perekonomian masyarakat di Indonesia, khususnya daya beli. Menurunnya pengeluaran per kapita memberikan indikasi bahwa daya beli masyarakat menurun dan pertumbuhan ekonomi melambat. Tujuan penelitian ini untuk mengetahui apakah terdapat perbedaan daya beli masyarakat sebelum dan saat terjadi pandemi Covid19, serta faktor-faktor yang memengaruhi daya beli masyarakat di Indonesia pada tahun 2020. Metode yang digunakan adalah uji beda rata-rata data berpasangan (dependen) dan regresi linear berganda pada 34 Provinsi di Indonesia pada tahun 2020. Hasil penelitian menunjukkan bahwa terdapat perbedaan yang signifikan antara daya beli masyarakat sebelum dan saat terjadi pandemi Covid-19. Terdapat amatan yang menjadi outlier dan leverage point, serta secara parsial tingkat pengangguran terbuka, jumlah realisasi proyek investasi, dan rata-rata lama sekolah berpengaruh secara signifikan terhadap daya beli masyarakat di Indonesia tahun 2020.
\end{abstract}

Kata kunci: Covid-19, daya beli, leverage point, outlier, regresi linear

\begin{abstract}
The Covid-19 pandemic that occurred in Indonesia prompted the government to issue a social restriction policy that had an impact on the economy of the people in Indonesia, especially purchasing power. The decline in per capita spending indicates that people's purchasing power is declining and economic growth is slowing. The purpose of this study is to find out whether there are differences in people's purchasing power before and during the Covid-19 pandemic, as well as the factors that affect people's purchasing power in Indonesia in 2020. The method used is the average difference test of paired data (dependent) and multiple linear regression in 34 provinces in Indonesia in 2020. The results show that there is a significant difference between people's purchasing power before and during the Covid-19 pandemic. Some observations become outliers and leverage points, as well as partially the open unemployment rate, the number of investment project realizations, and the average length of schooling have a significant effect on people's purchasing power in Indonesia in 2020.
\end{abstract}

Keywords: Covid-19, linear regression, purchasing power

\section{PENDAHULUAN}

Pembangunan manusia merupakan sebuah model pembangunan yang memiliki tujuan untuk meningkatkan kesempatan bagi seluruh komponen masyarakat dapat memiliki kehidupan yang layak dengan mengukurnya berdasarkan nilai IPM. IPM terdiri dari tiga dimensi dasar, salah satunya adalah standar hidup yang layak (decent standard of living). Standar hidup merupakan acuan yang berkaitan dengan tingkat kemakmuran atau kesejahteraan rata-rata yang digunakan sebagai ukuran minimal yang harus terpenuhi agar masyarakat mampu menjalani hidup yang layak (Gilarso, 2004). Badan Pusat Statistik menggunakan pengeluaran per kapita yang disesuaikan dalam mengukur standar hidup yang layak serta sebagai ukuran untuk daya beli masyarakat sebagai pendekatan dari pendapatan per kapita. Pengeluaran per kapita dapat menggambarkan besarnya daya beli yang dimiliki oleh masyarakat dalam melakukan konsumsi barang dan jasa (Yusuf \& Nurmalah, 2016). Rendahnya nilai daya beli dalam suatu masyarakat dapat menunjukkan bahwa kondisi perekonomian suatu wilayah pada suatu waktu mengalamai penurunan, sehingga menyebabkan rendahnya kemampuan dalam konsumsi barang dan jasa serta menurunnya standar hidup dari masyarakat untuk kesejahteraan hidupnya.

Pada awal Maret 2020, sejak diumumkannya kasus pertama Covid-19 di Indonesia, pemerintah mulai mengeluarkan kebijakan untuk mengurangi penyebaran virus Covid-19. Peraturan yang pertama adalah Pembatasan Sosial Berskala Besar (PSBB), Pemberlakukan Pembatasan Kegiatan Masyarakat (PPKM), 
PPKM Jawa-Bali, PPKM Mikro, PPKM Darurat, dan yang terakhir adalah PPKM Level 3 dan 4. Kebijakan pembatasan yang diberlakukan oleh pemerintah dalam rangka mengurangi penyebaran Covid-19 berdampak tidak hanya pada berpengaruh pada sisi sosial saja, tetapi juga perekonomian, pendidikan, dan layanan publik di Indonesia, khususnya tahun 2020. Pembatasan tersebut membuat banyak perusahaan harus membatasi barang yang akan diproduksi dan juga jumlah pekerja yang bekerja untuk mampu bertahan, sehingga berpengaruh terhadap menurunnya pendapatan perusahaan dan akhirnya berdampak pada terbatasnya biaya produksi sehingga membuat banyak pekerja terpaksa kehilangan pekerjaannya. Meningkatnya pengangguran selama pandemi Covid-19 membuat daya beli masyarakat menurun, karena banyak pekerja yang awalnya memiliki pendapatan menjadi terbatas, bahkan tidak memiliki pendapatan sama sekali, dan akhirnya memaksa mereka untuk mengurangi konsumsi barang dan jasa.

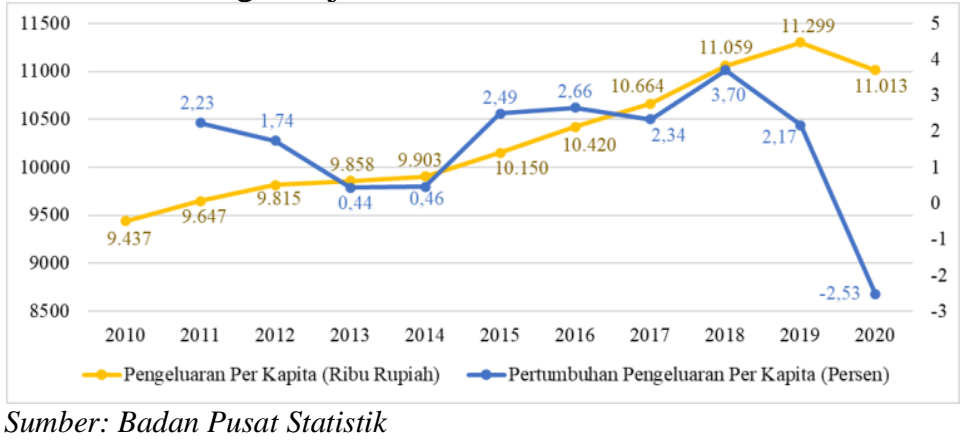

Gambar 1. Pengeluaran per Kapita yang Disesuaikan dan Pertumbuhan Pengeluaran per Kapita yang Disesuaikan, Tahun 2010-2020.

Gambar 1 menunjukkan pengeluaran per kapita yang disesuaikan dan pertumbuhan pengeluaran per kapita yang disesuaikan periode 2010-2020. Dalam rentang tahun 2010 hingga 2019 pengeluaran per kapita yang disesuaikan mengalami kenaikan tiap tahunnya dengan nilai rata-rata pertumbuhannya sebesar 2,02 persen per tahun, namun adanya pandemi Covid-19 membuat rata-rata pertumbuhan selama periode 20102020 menurun menjadi 1,73 persen per tahunnya. Pada tahun 2020 pengeluaran per kapita yang disesuaikan mengalami kontraksi hingga 2,53 persen menjadi sebesar Rp11.013.000 per tahun, turun sebesar Rp286.000 dibandingkan tahun sebelumnya. Nilai tersebut bahkan lebih rendah jika dibandingkan dengan tahun 2018 yang mencapai Rp1 1.059.000 per tahun. Dampak yang ditimbulkan dengan menurunnya daya beli masyarakat adalah menurunnya konsumsi rumah tangga mencapai minus 5,52 dan pertumbuhan ekonomi hingga minus 5,32 bahkan mencapai resesi ekonomi. Menurunnya pengeluaran per kapita akan berpengaruh langsung terhadap menurunnya konsumsi rumah tangga karena konsumsi rumah tangga berasal dari penjumlahan pengeluaran per kapita dalam suatu rumah tangga. Konsumsi rumah tangga yang menurun akan berdampak terhadap pertumbuhan ekonomi, karena pada tahun 2020 kontribusi konsumsi rumah tangga terhadap PDB mencapai 57,66 persen.

Disparitas pengeluaran per kapita tertinggi dan terendah mengalami kenaikan pada tahun 2020. Provinsi DKI Jakarta menempati posisi pertama sebagai provinsi dengan pengeluaran per kapita yang disesuaikan tertinggi yaitu sebesar Rp18.227.000, sedangkan Provinsi Papua sebagai provinsi yang memiliki capaian pengeluaran per kapita yang disesuaikan terendah yaitu sebesar Rp6.954.000 atau dapat dikatakan kurang dari separuh pengeluaran per kapita yang disesuaikan Provinsi DKI Jakarta. Sehingga menunjukkan bahwa standar hidup antar wilayah di Indonesia masih terdapat perbedaan yang signifikan.

Beberapa penelitian dilakukan untuk mengetahui faktor-faktor yang memengaruhi daya beli masyarakat. Penelitian yang dilakukan oleh Ayus dan Nurmalah (2016) dengan menggunakan metode analisis regresi panel memberikan hasil bahwa pendapatan per kapita, investasi, dan belanja pemerintah berpengaruh positif dan signifikan baik secara parsial maupun simultan (bersama - sama) terhadap daya beli masyarakat, sehingga memberikan kontribusi yang positif terhadap daya beli masyarakat. Zarkasi (2014) melakukan penelitian tentang pengaruh pengangguran terhadap daya beli masyarakat di Kalimantan Barat tahun 2002-2011 dengan menggunakan regresi linier berganda dan memberikan hasil tingkat pengangguran secara parsial berpengaruh negatif dan signifikan terhadap daya beli masyarakat. Yuniati dan Amini (2020) melakukan penelitian mengenai dampak Covid-19 terhadap daya beli masyarakat NTB dengan menggunakan metode deskriptif kualitatif dan memberikan hasil penelitian bahwa terjadi penurunan daya beli masyarakat di NTB yang disebabkan pandemi Covid-19.

Mengacu kepada permasalahan yang sudah dijelaskan, maka penelitian ini menguji secara statistik dengan uji beda rata-rata dua sampel dependen untuk mengetahui apakah terdapat perbedaan yang signifikan antara daya beli masyarakat sebelum dan saat terjadi pandemi Covid-19, dan penelitian ini untuk mengetahui sebaran 
pengeluaran per kapita sebagai indikator daya beli masyarakat dan standar hidup di Indonesia, serta faktorfaktor yang memengaruhi daya beli masyarakat di Indonesia pada tahun 2020, karena pentingnya daya beli masyarakat sebagai salah satu penopang perekonomian yang cukup penting terutama dalam kondisi pandemi Covid-19 saat ini, serta sebagai pedoman dalam pembuatan kebijakan yang tepat, efektif, dan efisien yang dapat menjaga kestabilan atau meningkatkan daya beli masyarakat di Indonesia. Hipotesis yang diajukan dalam penelitian ini adalah indeks implisit PDRB, PDRB per kapita, jumlah realisasi proyek investasi, tingkat pengangguran terbuka, dan rata-rata lama sekolah berpengaruh signifikan terhadap pengeluaran per kapita atau daya beli masyarakat selama pandemi Covid-19 tahun 2020.

\section{METODE}

Data yang digunakan dalam penelitian ini merupakan data sekunder, menggunakan metode studi kepustakaan dengan mencari data dan informasi dari sumber-sumber yang relevan terhadap penelitian ini. Dalam penelitian ini, data yang digunakan adalah data cross section seluruh provinsi di Indonesia (34 provinsi) pada tahun 2020 yang diperoleh dari publikasi-publikasi yang dikeluarkan oleh Badan Pusat Statistik. Variabel yang digunakan adalah pengeluaran per kapita, indeks implisit PDRB, PDRB per kapita, tingkat pengangguran terbuka, realisasi proyek investasi, dan rata-rata lama sekolah di Indonesia tahun 2020. Metode analisis yang digunakan adalah uji beda rata-rata dua sampel dependen dan analisis regresi linear berganda. Kemudian dilakukan pengecekan leverage point, outlier, dan amatan berpengaruh, serta pengujian asumsi klasik.

\section{Daya Beli}

Badan Pusat Statistik mendefinisikan daya beli merupakan kemampuan masyarakat untuk membelanjakan uangnya dalam bentuk barang atau jasa. Dr. Supawi Pawengan dalam Yuniati dan Amini (2020) menjelaskan bahwa daya beli merupakan kemampuan dari masyarakat sebagai seorang konsumen dalam kegiatannya membeli barang maupun jasa yang dibutuhkannya. Daya beli masyarakat ditandai dengan meningkat atau menurun, dimana dikatakan meningkat apabila daya beli masyarakat lebih tinggi dibandingkan dengan periode sebelumnya, sedangkan menurun apabila daya beli masyarakat periode sebelumnya lebih tinggi. Putong (2003) dalam Hernaningsih (2018) mengartikan daya beli merupakan suatu kemampuan yang dimiliki konsumen dalam membeli sejumlah barang yang dibutuhkannya pada suatu pasar tertentu, pada tingkat pendapatan tertentu, dan dalam periode waktu tertentu.

\section{Uji beda rata-rata dua sampel dependen (paired sample t-test)}

Pengujian dua sampel berpasangan merupakan salah satu pengujian uji parametrik yang digunakan untuk menganalisis apakah terdapat perbedaan antara dua sampel berpasangan. Dalam pengujian dua sampel dependen, masing-masing kelompok saling memengaruhi atau berkorelasi satu sama lain (Pramana, Yordani, Kurniawan, \& Yuniarto, 2017). Hipotesis nol dalam uji ini yaitu bahwa rata-rata selisih dari kedua populasi sama atau tidak berbeda. Statistik uji yang digunakan adalah sebagai berikut:

dimana:

$$
t^{*}=\frac{\bar{d}-\mu_{d}}{s_{d} / \sqrt{n}}
$$

$\bar{d} \quad=$ rata-rata selisih antara dua kelompok sampel setiap amatan

$\mu_{d}=$ rata-rata dari selisih parameter

$s_{d}=$ standar deviasi dari selisih dari dua kelompok pada setiap amatannya

$\mathrm{N}=$ jumlah amatan

\section{Regresi Linear Berganda}

Analisis regresi merupakan suatu alat statistik yang memanfaatkan hubungan antara dua variabel kuantitatif atau lebih sehingga satu variabel dapat diprediksi dari variabel - variabel lainnya. Hubungan fungsional antara dua variabel dinyatakan dengan rumus matematika. $\mathrm{X}$ adalah variabel bebas dan $\mathrm{Y}$ merupakan variabel tak bebas. Model regresi merupakan suatu langkah untuk mengekspresikan dua atau lebih bahan (ingredients) di dalam sebuah hubungan statistik (statistical relation) antara variabel bebas dan tak bebas (Neter, Wasserman, \& Kutner, 1983).

Analisis regresi linear berganda merupakan teknik statistik yang biasanya digunakan dalam menganalisis pengaruh yang diakibatkan oleh sejumlah variabel bebas kepada variabel tak bebas. Hal yang membedakan antara regresi linear sederhana dengan regresi linear berganda adalah jumlah variabel bebasnya, variabel bebas 
di analisis regresi linear sederhana hanya satu variabel, sedangkan untuk regresi linear berganda terdapat lebih dari satu variabel bebas. Analisis regresi berganda akan dilakukan apabila jumlah variabel bebasnya minimal 2 variabel. Persamaan dari regresi linear berganda adalah sebagai berikut:

$$
Y_{i}=\beta_{0}+\beta_{1} X_{1 i}+\beta_{2} X_{2 i}+\cdots+\beta_{k} X_{k i}+\varepsilon_{i}
$$
dimana:

$Y_{i}=$ variabel respons

$\beta_{0}=$ konstanta

$X_{i j}=$ variabel penjelas

$\beta_{k}=$ koefisien regresi

$\varepsilon_{i}=$ error

Salah satu metode yang dapat digunakan untuk melakukan estimasi parameter regresi linear adalah metode kuadrat terkecil (OLS). Metode kuadrat terkecil bertujuan untuk memperoleh nilai estimasi untuk $\beta_{0}$ dan $\beta_{k}$ yang memberikan hasil jumlah kesalahan kuadrat (sum of square error) minimum. Terdapat beberapa asumsi yang harus dipenuhi jika menggunakan metode kuadrat terkecil (OLS) pada regresi linear sederhana maupun regresi linear berganda (Basuki \& Prawoto, 2015), hal tersebut agar model yang diperoleh merupakan Best Linear Unbiased Esimation (BLUE), asumsi-asumsi tersebut adalah:

a) Nilai harapan (Expected Value) residual adalah nol $(E(\varepsilon)=0)$ untuk setiap i.

b) Tidak terdapat korelasi antara variabel $\operatorname{error}\left(\operatorname{Cov}\left(\varepsilon_{i}, \varepsilon_{j}\right)=0\right)$, untuk setiap $\mathrm{i} \neq \mathrm{j}$.

c) Varians dari variabel error adalah sama $\left(\operatorname{Var}\left(\varepsilon_{i}\right)=\sigma^{2}\right)$, untuk setiap i. Sehingga error memiliki sebaran yang sama (homoscedasticity).

d) Variabel error berdistribusi normal $\left(\varepsilon_{i} \sim N\left(0, \sigma^{2}\right)\right)$.

e) Hubungan antara variabel tak bebas $(\mathrm{Y})$ dan variabel bebas $(\mathrm{X})$ adalah linear di dalam parameter.

f) Tidak terdapat hubungan linear antara variabel bebas atau tidak ada multikolinearitas antara masing-masing variabel bebas.

\section{Leverage Point}

Leverage point adalah amatan atau observasi yang memiliki nilai diagonal hat matrix yang tinggi. Leverage point dapat menarik garis regresi ke arah amatan tersebut, sehingga berpotensi mendistorsi model yang digunakan. Selain itu memiliki efek yang kuat pada ukuran kekuatan hubungan regresi yang diamati yang memiliki pengaruh kuat pada regresi yang nilai variabel bebas $(x)$ berbeda dari nilai variabel bebas lainnya (unusual predictor value). Dalam menentukan leverage point pada variabel bebas $(x)$ dihitung dengan leverage pada model regresi, yang mana diukur oleh diagonal elemen dari $h_{i i}$ dari hat matrix (Chatterjee, 2013).

$$
h_{i i}=x_{i}^{\prime}\left(X^{\prime} X\right)^{-1} x_{i}
$$
dimana:

$h_{i i}=$ diagonal utama hat matrix

$x_{i}=$ variabel bebas amatan ke-i

Ketika nilai $h_{i i}>2(k+1) / n$ maka dapat dikatakan bahwa observasi atau amatan tersebut merupakan leverage point. Sehingga nilai hat diagonal yang lebar menunjukkan observasi yang berpotensi berpengaruh karena jaraknya jauh dari keseluruhan amatan.

\section{Outlier}

Outlier atau pencilan merupakan observasi dengan nilai mutlak residual yang besar, sehingga menunjukkan nilai respon $\hat{y}_{i}$ yang relatif tidak biasa terhadap nilai yang diharapkan (Chatterjee, 2013). Adanya data pencilan ini dapat membuat analisis menjadi bias terhadap serangkaian data dan juga tidak mencerminkan fenomena yang terjadi dengan sebenarnya. Salah satu pendekatan untuk mengetahui adanya pencilan adalah membuat plot residual $\hat{\varepsilon}_{i}$ dengan $\hat{y}_{i}$, atau dengan $i$, jumlah observasi. Pendekatan lain untuk melihat apakah terdapat pencilan dapat menggunakan beberapa metode seperti externally studentized residual atau yang biasa disebut dengan Studentized Deleted Residual ( $R$ Student).

Keterangan:

$$
t_{i}=\frac{e_{i}}{s_{(i)} \sqrt{1-h_{i i}}}
$$

$e_{i} \quad=$ sisaan pada model regresi

$s_{i}=$ standard error yang dihitung tanpa amatan ke-i (n-1 amatan)

$h_{i i}=$ diagonal utama hat matrix 
Suatu amatan diduga sebagai outlier apabila amatan tersebut memiliki nilai $\left|t_{i}\right|>t_{\frac{\alpha}{2} ; n-k-1}$.

\section{Amatan Berpengaruh}

Amatan berpengaruh merupakan amatan yang dapat menarik model regresi menuju amatan tersebut, sehingga akan berpengaruh terhadap koefisien model regresi yang diperoleh (Montgomery, Peck, \& Vining, 2012) atau merupakan pengamatan yang penghapusannya menyebabkan perubahan besar dalam regresi yang dipasang (Chatterjee, 2013). Metode yang dapat digunakan adalah menggunakan ukuran nilai DFBETAS, DFFITS, COVRATIO atau Cook's Distance dalam melakukan analisis untuk amatan yang berpengaruh terhadap model regresi. Apabila menggunakan software R-Studio dapat menggunakan influence.measures untuk memperoleh kesimpulan amatan yang menjadi amatan berpengaruh.

\section{HASIL DAN PEMBAHASAN}

Pada tahun 2020 pandemi Covid-19 menyebabkan perekonomian global menyusut, tak terkecuali Indonesia. Hal tersebut memberikan dampak kepada mekanisme pasar dimana terganggungnya permintaan dan penawaran dengan adanya kebijakan pembatasan sosial. Fenomena tersebut tercermin dari menurunnya pengeluaran per kapita seluruh provinsi di Indonesia dibandingkan dengan tahun 2019. Berdasarkan Badan Pusat Statistik, rendahnya daya beli masyarakat membuat konsumsi rumah tangga mengalami kontraksi hingga 2,53 persen. Hal tersebut tercermin dari indikator penjualan eceran yang mengalami kontraksi hingga 12,03 persen, impor barang konsumsi yang terkontraksi 10,93 persen, dan penjualan wholesale mobil penumpang dan sepeda motor yang terkontraksi masing-masing sebesar 50,49 persen dan 43,54 persen. PDRB per kapita dan rata-rata lama sekolah juga mengalami perlambatan dalam pertumbuhannya. Sedangkan indeks implisit PDRB, jumlah realisasi proyek investasi, dan tingkat pengangguran terbuka cenderung mengalami peningkatan. Kenaikan tingkat pengangguran terbuka terjadi di seluruh provinsi di Indonesia, dan secara nasional tingkat pengangguran terbuka di Indonesia meningkat menjadi 7,07 persen atau 9,77 juta orang.

\section{Grafik Boxplot}

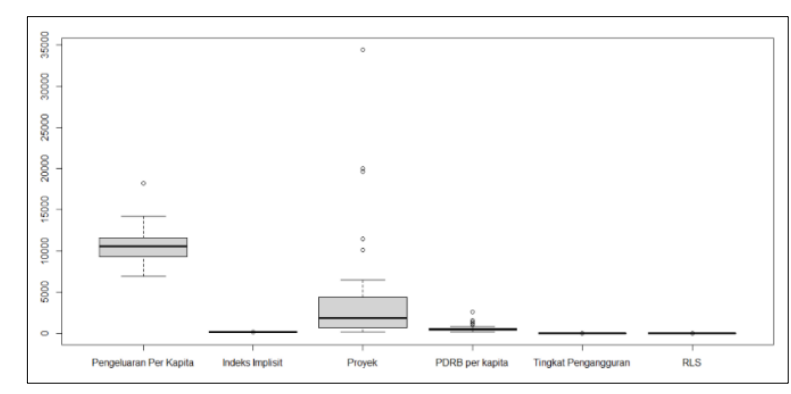

Sumber: Badan Pusat Statistik, diolah

Gambar 2. Sebaran variabel dengan menggunakan boxplot.

Gambar 2 menunjukkan bahwa dari variabel-variabel yang digunakan terdapat cukup banyak amatan yang memiliki nilai yang jauh dibandingkan nilai yang lainnya, hal ini karena adanya amatan yang menjadi outlier yang berada diluar boxplot. Variabel realisasi proyek investasi memiliki amatan yang menjadi outlier cukup banyak, hal ini menunjukkan bahwa dalam merealisasikan proyek investasi tiap wilayah di Indonesia cenderung berbeda, terdapat wilayah yang sedikit dalam melakukan realisasi, dan terdapat daerah yang cukup banyak dalam melakukan realisasi proyek. Sedangkan untuk variabel pengeluaran per kapita yang digunakan sebagai indikator daya beli masyarakat, terdapat satu amatan yang menjadi outlier yaitu DKI Jakarta, hal ini menunjukkan bahwa daya beli masyarakat di wilayah DKI Jakarta cukup tinggi dibandingkan wilayah lain di Indonesia, karena merupakan daerah pusat perekonomian dan pemerintahan di Indonesia.

\section{Hasil Uji Beda Rata-Rata Dua Sampel Dependen}

Pengujian uji rata-rata dua sampel dependen untuk mengetahui apakah terdapat perbedaan antara daya beli masyarakat sebelum adanya pandemi Covid-19 (2019) dan saat terjadi pandemi Covid-19 (2020). Berdasarkan uji normalitas menggunakan shapiro wilk menunjukkan bahwa sampel yang digunakan tidak berdistribusi normal, karena nilai $p$-value $<0,05$ sehingga menunjukkan bahwa sampel tidak berdistribusi normal, maka menggunakan asumsi Central Limit Theorem (CLT) untuk dapat melakukan uji beda 
berpasangan karena data yang digunakan termasuk sampel besar atau lebih dari 30 amatan. Hasil yang diperoleh adalah sebagai berikut:

Tabel 1. Output uji rata-rata dua sampel dependen

\begin{tabular}{|c|c|c|}
\hline & 2019 & 2020 \\
\hline Rata-Rata & 10915,59 & 10685.79 \\
\hline Varians & 4899431,22 & 4780278,78 \\
\hline Pearson Correlation & & \\
\hline $\boldsymbol{t}^{*}$ & & \\
\hline$t_{t a b e l}$ & & \\
\hline p-value & & \\
\hline
\end{tabular}

Keterangan: * Signifikan pada $\alpha=5$ persen

Tabel 1 menunjukkan hasil pengujian rata-rata dua sampel dependen, diperoleh hasil bahwa rata-rata pengeluaran per kapita pada tahun 2019 adalah sebesar Rp10.915.588, sedangkan pada tahun 2020 sebesar Rp10.685.794, sehingga menunjukkan bahwa terdapat penurunan rata-rata pengeluaran per kapita pada tahun 2020. Korelasi antara dua kelompok juga sangat kuat yaitu sebesar 0,99 yang menunjukkan bahwa kedua sampel yang digunakan saling berpengaruh atau dependen. Nilai $t^{*}$ sebesar 8,8146 lebih besar dibandingkan nilai kritis $\mathrm{t}$ yaitu sebesar 2,0345, selain itu nilai $p$-value sebesar 0,000 lebih kecil dari 0,05, sehingga keputusannya adalah Tolak $H_{0}$. Maka kesimpulan yang diperoleh yaitu terdapat cukup bukti untuk menyatakan terjadi perbedaan yang signifikan antara pengeluaran per kapita sebelum dan saat terjadi pandemi Covid-19. Hal ini sesuai dengan penelitian yang dilakukan oleh Sayuti dan Hidayati (2020) bahwa masyarakat telah melakukan adaptasi atau kebiasaan baru dalam perekonomiannya saat pandemi Covid-19 dengan cara menghemat atau melakukan efisiensi dalam pengeluarannya. Hal tersebut dilakukan oleh masyarakat karena melakukan pencegahan kemungkinan terburuk seperti menurunnya pendapatan, terjadinya peningkatan pengeluaran dan kemungkinan untuk diberhentikan bekerja hingga sempitnya lapangan pekerjaan.

\section{Hasil Regresi Linear Berganda}

Berdasarkan hasil pengolahan dengan menggunakan software R-Studio 4.1.0 diperoleh model regresi linier berganda sebagai berikut:

Tabel 2. Ringkasan output model regresi linear berganda

\begin{tabular}{ccccc}
\hline & Koefisien & $S E$ & $t$-value & P-Value \\
\hline Konstanta & 7,30251 & 1,93971 & 3,765 & $0,001^{*}$ \\
ln_Indeks Implisit & $-0,16007$ & 0,38173 & $-0,419$ & 0,678 \\
ln_PDRB per Kapita & 0,03848 & 0,04729 & 0,814 & 0,423 \\
ln_TPT & $-0,16512$ & 0,10488 & $-1,574$ & 0,127 \\
ln_Proyek & 0,10031 & 0,02164 & 4,636 & $0,000^{*}$ \\
ln_RLS & 0,86652 & 0,25135 & 3,448 & $0,002^{*}$ \\
R-Squared & \multicolumn{2}{c}{0,6496} \\
Adjusted $R$-Squared & \multicolumn{2}{c}{0,587} \\
F-Statistic & \multicolumn{2}{c}{0,38} \\
Prob(F-Statistic) & \multicolumn{3}{c}{$0,000^{*}$} \\
\hline
\end{tabular}

Keterangan: * Signifikan pada $\alpha=5$ persen

Tabel 2 menunjukkan hasil dari pengolahan untuk model persamaan regresi linear berganda. Hasil yang diperoleh menunjukkan bahwa nilai koefisien determinasi adalah sebesar 0,6496 dan nilai adjusted $R$-Square sebesar 0,587 artinya dengan variabel bebas yang ada, dapat menjelaskan keragaman pengeluaran per kapita atau daya beli masyarakat sebesar 58,7 persen. Secara parsial, variabel yang signifikan hanya variabel realisasi proyek investasi dan rata-rata lama sekolah. Sedangkan variabel indeks implisit PDRB, PDRB per kapita, dan tingkat pengangguran tidak signifikan. Setelah memperoleh model persamaan regresi, maka selanjutnya adalah melakukan pemeriksaan leverage point, outlier, dan juga amatan yang berpengaruh. 
Tabel 3. Amatan yang menjadi leverage point

\begin{tabular}{cccc}
\hline Amatan & $\boldsymbol{h}_{\boldsymbol{i i}}$ & nilai batas & Keputusan \\
\hline 11 & 0,4187 & 0,3529 & Leverage Point \\
31 & 0,3757 & 0,3529 & Leverage Point \\
33 & 0,4097 & 0,3529 & Leverage Point \\
\hline
\end{tabular}

Berdasarkan hasil yang diperoleh pada tabel 3 diperoleh kesimpulan bahwa amatan ke-11, 31, dan 33 merupakan leverage point yang menunjukkan bahwa amatan-amatan tersebut memiliki nilai $\mathrm{x}$ yang tidak biasa (unusual predictor). Hal tersebut karena nilai dari $h_{i i}>$ nilai batas, yaitu 0,3529 , sehingga memberikan kesimpulan bahwa terdapat tiga amatan yang menjadi leverage point. Setelah melakukan pengecekan leverage point, selanjutnya adalah pengecekan outlier.

Berdasarkan tabel 4 diperoleh hasil bahwa amatan ke-9 merupakan sebuah outlier, karena memiliki nilai $\mid R-$ Student $\mid$ lebih besar dari t-tabel sebesar 2,048.

Tabel 4. Amatan yang menjadi outlier

\begin{tabular}{cccc}
\hline Amatan & R-Student & $\boldsymbol{t}_{\mathbf{0 , 0 2 5} \mathbf{2 8}}$ & Keputusan \\
\hline 9 & 2,5093 & 2,048 & Outlier \\
\hline
\end{tabular}

Hasil tersebut menunjukkan bahwa hanya amatan ke-9 yang memiliki nilai fitted value yang berbeda dibandingkan keseluruhan amatan, sehingga diperoleh kesimpulan amatan ke-9 merupakan amatan yang menjadi outlier. Apabila digambarkan ke dalam sebuah plot, maka dapat menggunakan gambar 3 untuk mengetahui amatan yang menjadi outlier dan leverage point.

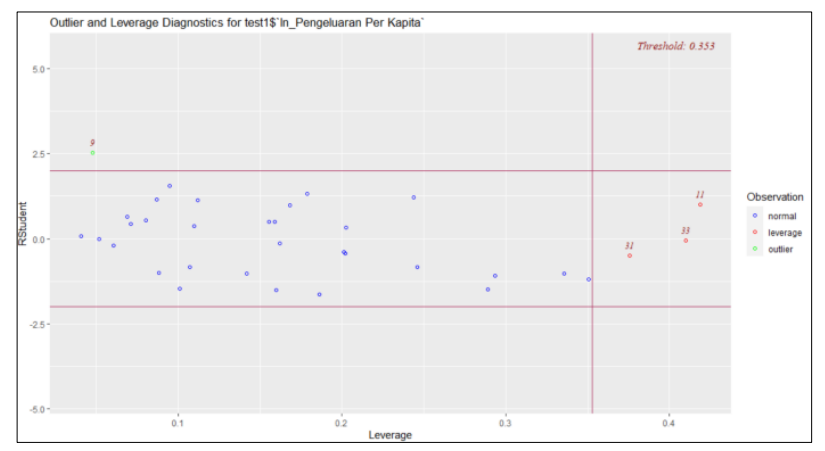

Gambar 3. Outlier dan leverage point

Selanjutnya yaitu mengetahui amatan yang berpengaruh, hasil yang diperoleh dengan menggunakan bantuan software R-studio dengan influence.measures diperoleh hasil ringkasan bahwa terdapat tiga amatan yang berpengaruh terhadap model regresi linear berganda yaitu amatan ke-11, 31, dan 33 .

Tabel 5. Hasil identifikasi leverage Point, outlier, dan amatan berpengaruh

\begin{tabular}{cccc}
\hline & \multicolumn{3}{c}{ Amatan ke- } \\
\hline $\begin{array}{c}\text { Leverage Point } \\
\text { Outlier }\end{array}$ & 11 & 31 & 33 \\
Amatan Berpengaruh & 09 & 31 & 33 \\
\hline
\end{tabular}

Tabel 5 menunjukkan amatan -amatan yang menjadi Leverage Point, Outlier, dan amatan berpengaruh, dan diperoleh kesimpulan bahwa amatan ke- 11, 31, dan 33 amatan yang berpengaruh dan juga termasuk leverage point. Maka dapat dikatakan bahwa amatan ke-9 termasuk outlier dan bukan termasuk amatan yang berpengaruh terhadap model regresi, maka dilakukan pemeriksaan apakah dengan membuang amatan ke-9 akan meningkatkan nilai $R$-Square dan Adjusted $R$-Square, serta dapat menurunkan nilai $R S E$ dan AIC.

Tabel 6. Perbandingan nilai $R$-Square, Adjusted R-Square, AIC, dan RSE

\begin{tabular}{ccccc}
\hline & $\boldsymbol{R}$-Square & Adjusted $\boldsymbol{R}$-Square & AIC & $\boldsymbol{R S E}$ \\
\hline Semua amatan & 0,650 & 0,587 & $-37,9$ & 0,1244 \\
Tanpa amatan ke-9 & 0,707 & 0,652 & $-42,3$ & 0,1139 \\
\hline
\end{tabular}

Tabel 6 menunjukkan perbedaan nilai $R$-Square, Adjusted $R$-Square, dan Mean Square Error ketika menggunakan semua amatan dan tanpa amatan ke-9. Ketika menggunakan semua amatan nilai $R^{2}$ dan 
Adjusted $R^{2}$ lebih kecil dan nilai AIC dan RSE lebih besar dibandingkan saat tidak menggunakan amatan ke9. Namun nilai $R^{2}$ dan Adjusted $R^{2}$ terbesar, serta nilai AIC dan MSE terkecil saat tidak menggunakan amatan ke-9 untuk membuat model persamaan regresi linear berganda, yaitu sebesar 0,707 untuk $R^{2}, 0,652$ untuk Adjusted $R^{2}$, AIC sebesar -42,3 dan nilai RSE sebesar 0,1139. Maka amatan tersebut dapat dieliminasi atau tidak digunakan dalam membuat model persamaan regresi.

Sehingga persamaan model regresi yang didapatkan akan menjadi berikut:

Tabel 7. Ringkasan output model regresi linear berganda tanpa outlier

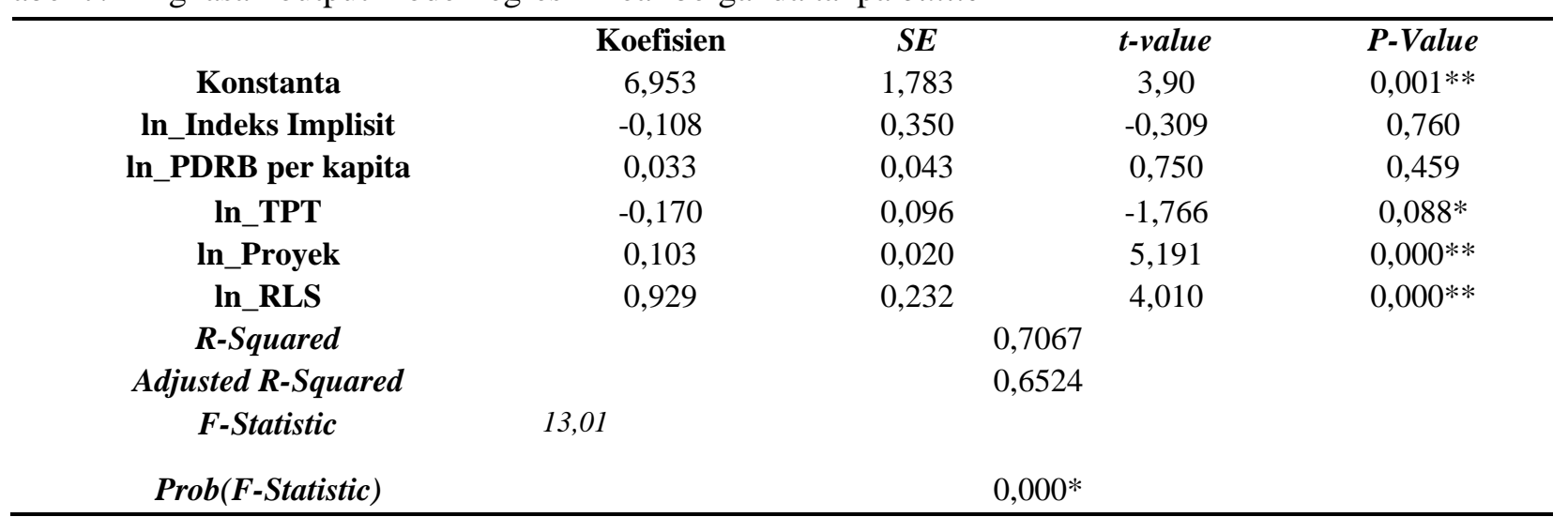

Keterangan: * Signifikan pada $\alpha=10$ persen

** Signifikan pada $\alpha=5$ persen

Berdasarkan hasil estimasi persamaan regresi yang kedua pada tabel 7 menghasilkan nilai yang sedikit berbeda pada nilai koefisiennya, hal ini terjadi karena menurunnya nilai koefisien standar error yang menyebabkan nilai $R^{2}$ dan nilai Adjusted $R^{2}$ meningkat daripada sebelumnya. Nilai $R^{2}$ dan nilai Adjusted $R^{2}$ mengalami peningkatan dengan nilai sebelumnya sebesar 64,96 persen dan 58,7 persen, setelah dikeluarkan amatan yang menjadi pencilan dalam model regresi maka menjadi 70,67 persen dan 65,24 persen. Hasil Adjusted $R$-Square yang diperoleh adalah sebesar 65,24 persen, memberikan arti bahwa variabel bebas yang terdapat di dalam model (indeks implisit PDRB, PDRB per kapita, tingkat pengangguran, proyek investasi, rata-rata lama sekolah) mampu menjelaskan keragaman pengeluaran per kapita atau daya beli masyarakat di Indonesia tahun 2020 sebesar 65,24 persen, sisanya sebesar 34,76 persen sisanya dapat dijelaskan oleh variabel lain di luar model.

\section{Uji Asumsi Klasik}

Berikut merupakan hasil pengujian dari asumsi klasik yang dihasilkan dalam penelitian ini:

\section{Normalitas}

Dalam melakukan uji normalitas menggunakan Jarque-Bera test. Berdasarkan hasil pengolahan besarnya nilai $p$-value adalah sebesar 0,4293 dimana nilainya lebih besar daripada tingkat signifikansi atau $\alpha=0,05$. Sehingga keputusannya Gagal Tolak $H_{0}$, maka kesimpulannya adalah tidak terdapat cukup bukti untuk menyatakan bahwa residual tidak berdistribusi normal (residual berdistribusi normal).

\section{Heteroskedastisitas}

Uji heteroskedastisitas dalam penelitian ini menggunakan Breusch Pagan test. Diperoleh hasil bahwa nilai $p$-value yaitu sebesar 0,4063 dimana nilainya lebih besar dari tingkat signifikansi atau $\alpha=0,05$. Sehingga keputusannya adalah Gagal Tolak $H_{0}$, maka dapat disimpulkan bahwa tidak terdapat cukup bukti untuk menyatakan terjadi pelanggaran asumsi heteroskedastisitas.

\section{Multikolinearitas}

Pengujian multikolineritas dilakukan dengan melihat nilai VIF (Variance Inflation Factor) dari masingmasing variabel bebas. Berdasarkan output pada lampiran 2 diperoleh hasil bahwa seluruh variabel bebas yaitu indeks implisit PDRB, PDRB per kapita, tingkat pengangguran, proyek investasi, dan rata-rata lama sekolah memiliki nilai VIF kurang dari 10. Maka dapat disimpulkan bahwa tidak terjadi pelanggaran asumsi multikolinieritas.

\section{Persamaan Regresi Linear Berganda}

Model yang diperoleh setelah pengecekan leverage point, outlier dan amatan berpengaruh, serta pengujian asumsi klasik adalah sebagai berikut: 
In_Pengeluaran per Kaplta ${ }_{i}=6,953-0,108$ ln_IndeksImplisit $_{i}+$ 0,033 ln_PDRBperKapita $_{i}-0,170$ ln_TPT ${ }_{i}^{*}+0,103$ ln_Proyek $_{i}^{* *}+0,929 \ln _{-} R L S_{i}{ }^{* *}$

Keterangan: * Signifikan pada $\alpha=10$ persen

** Signifikan pada $\alpha=5$ persen

Berdasarkan hasil yang diperoleh koefisien pertumbuhan (laju) indeks implisit PDRB memiliki pengaruh negatif namun tidak signifikan terhadap pertumbuhan pengeluaran per kapita deng an koefisien regresi sebesar 0,108 . Hal tersebut karena apabila terjadi kenaikan harga, kenaikan tersebut tidak akan berpengaruh langsung terhadap masyarakat, karena banyaknya masyarakat yang mengalami penurunan pendapatan sehingga mengakibatkan menurunnya daya beli, maka masyarakat lebih cenderung untuk berhemat meskipun terjadi penurunan harga barang maupun jasa. Hal ini sesuai dengan penelitian Sayuti dan Hidayati (2020), masyarakat saat pandemi Covid-19 mengalami perubahan dalam hal konsumsi, karena menurunnya pendapatan sehingga akan cenderung untuk meningkatkan konsumsi barang-barang kebutuhan pokok seperti makanan dan kebutuhan sehari-hari yang dianggap lebih dibutuhkan selama adanya pembatasan sosial. Sedangkan koefisien pertumbuhan PDRB per kapita memiliki pengaruh positif dan tidak signifikan terhadap pertumbuhan pengeluaran per kapita dengan koefisien regresi sebesar 0,033. Meningkatnya PDRB per kapita akan mampu meningkatkan pengeluaran per kapita, sehingga akan membuat daya beli masyarakat dapat meningkat namun karena adanya pandemi Covid-19 yang membuat banyaknya pekerja yang mengalami PHK, sehingga meskipun terjadi kenaikan maupun penurunan pada sektor-sektor penyusun PDRB tidak akan berpengaruh, karena pekerja tersebut sudah tidak bekerja dan memperoleh pendapatan. Selain itu sebagian besar sektor lapangan usaha penyusun PDB mengalami kontraksi atau penurunan, sehingga implikasinya adalah menurunnya keuntungan dan pendapatan yang diperoleh oleh masyarakat yang masih bekerja.

Koefisien pertumbuhan tingkat pengangguran terbuka memiliki pengaruh negatif dan signifikan dengan tingkat signifikansi 10 persen terhadap pertumbuhan pengeluaran per kapita dengan memiliki koefisien regresi sebesar -0,170, artinya apabila pertumbuhan tingkat pengangguran terbuka meningkat sebesar 1 persen, maka pertumbuhan pengeluaran per kapita akan mengalami penurunan sebesar 0,170 persen, dengan asumsi ceteris paribus. Hasil yang diperoleh sesuai dengan hasil penelitian Zarkasi (2014) dimana tingkat pengangguran berpengaruh negatif dan signifikan terhadap daya beli masyarakat. Pengangguran akan berdampak buruk terhadap perekonomian yang berpengaruh terhadap pendapatan masyarakat. Masyarakat yang menganggur akan cenderung berkurang pendapatannnya, bahkan tidak memiliki pendapatan untuk memenuhi kebutuhan hidupnya, sehingga akan berpengaruh kepada pengeluaran per kapitanya akan mengalami penurunan sehingga daya beli masyarakat akan berkurang.

Koefisien pertumbuhan realisasi proyek investasi dan rata- rata lama sekolah memiliki pengaruh positif dan signifikan pada tingkat signifikansi 5 persen terhadap pertumbuhan pengeluaran per kapita, dimana untuk pertumbuhan realisasi proyek investasi dengan nilai koefisien regresi sebesar 0,103 artinya ketika pertumbuhan realisasi proyek investasi meningkat sebesar 1 persen, maka pertumbuhan pengeluaran per kapita akan mengalami kenaikan sebesar 0,103 persen, dengan asumsi ceteris paribus. Hasil yang diperoleh sesuai dengan Yusuf dan Nurmalah (2016) bahwa investasi berpengaruh terhadap pengeluaran per kapita. Semakin besar tingkat investasi maka akan menambah pendapatan yang diterima, karena proyek investasi akan meningkatkan lapangan pekerjaan dan taraf hidup masyarakat dengan meningkatnya pendapatan yang diperoleh. Maka dengan semakin besarnya pendapatan yang diterima maka akan berdampak pula pada daya beli masyarakat. Sehingga proyek investasi akan berpengaruh positif terhadap daya beli masyarakat.

Pertumbuhan rata-rata lama sekolah memiliki nilai koefisien regresi sebesar 0,929 , artinya ketika pertumbuhan rata-rata lama sekolah meningkat sebesar 1 persen, maka pertumbuhan pengeluaran per kapita akan mengalami kenaikan sebesar 0,929 persen, dengan asumsi ceteris paribus. Hasil tersebut sesuai dengan penelitian Adiana dan Karmini (2012) bahwa pendidikan berpengaruh positif dan signifikan terhadap konsumsi, artinya semakin tinggi pendidikan yang ditempuh oleh masyarakat maka konsumsi masyarakat juga akan meningkat sehingga hubungannya akan positif antara pendidikan dengan pengeluaran. Pendidikan merupakan investasi yang penting, karena ketika seseorang memperoleh pendidikan yang tinggi, maka kemampuan dan pengetahuan yang dimiliki semakin tinggi sehingga mampu memperoleh pekerjaan yang lebih baik. Selain itu, saat seseorang memiliki pendidikan yang tinggi kebutuhan hidupnya semakin banyak, karena kebutuhan yang harus dipenuhi tidak hanya kebutuhan untuk makan dan minum, tetapi juga kebutuhan untuk memperoleh informasi. Sehingga dengan pendidikan seseorang berpeluang untuk dapat meningkatkan kesejahteraannya. 


\section{KESIMPULAN}

Pada tahun 2020 dengan adanya pandemi Covid-19 di Indonesia memberikan dampak pada penurunan daya beli masyarakat, dimana perbedaan yang terjadi signifikan apabila dibandingkan dengan daya beli masyarakat tahun 2019 atau sebelum terjadi penyebaran Covid-19 di Indonesia. Amatan ke-9 merupakan outlier dan setelah dieliminasi meningkatkan nilai $R$-Square dan Adjusted $R$-Square serta menurunkan nilai $A I C$ dan $R S E$ sehingga hasil yang diperoleh lebih baik dibandingkan saat terdapat amatan ke-9, sedangkan amatan ke-11,31, dan 33 merupakan leverage point dan amatan berpengaruh. Terdapat tiga variabel yang signifikan terhadap daya beli masyarakat di Indonesia pada tahun 2020, yaitu tingkat pengangguran terbuka, jumlah realisasi proyek investasi, dan rata-rata lama sekolah. Semakin tinggi jumlah tingkat pengangguran terbuka atau masyarakat yang tidak memiliki pekerjaan akan menurunkan pendapatannya sehinga daya beli menurun. Semakin banyak realisasi proyek investasi yang dilakukan maka akan semakin meningkatkan lapangan pekerjaan sehingga masyarakat yang menganggur dapat kembali bekerja untuk memenuhi kebutuhan hidupnya. Tingkat Pendidikan juga berpengaruh terhadap daya beli masyarakat karena masyarakat yang memiliki Pendidikan yang tinggi akan cenderung memiliki pekerjaan yang layak dengan upah atau gaji yang sesuai sehingga kebutuhannya akan terpenuhi.

Adanya pandemi Covid-19 telah berpengaruh secara signifikan terhadap pola kehidupan ekonomi masyarakat, dengan menurunnya pendapatan yang diterima, pola pengeluaran untuk kehidupan sehari-hari yang perlu diatur dan lapangan pekerjaan yang semakin menurun. Pemerintah diharapkan mampu membuat kebijakan yang sesuai dengan keadaan dan kebutuhan masyarakat, mengingat semakin banyaknya masyarakat yang terkena dampak terhadap adanya kebijakan pembatasan sosial yang berpengaruh terhadap segala aspek, terutama terhadap variabel-variabel yang memiliki pengaruh terhadap daya beli masyarakat pada tahun 2020 . Hal tersebut dilakukan sebagai upaya dalam mempercepat pemulihan perekonomian di Indonesia, karena tinggi kontribusi konsumsi masyarakat terhadap PDB di Indonesia.

\section{DAFTAR PUSTAKA}

Adiana, Pande P.E. dan Karmini, Ni Luh. 2012. Pengaruh Pendapatan, Jumlah Anggota Keluarga, dan Pendidikan terhadap Pola Konsumsi Rumah Tangga Miskin di Kecamatan Gianyar. Jurnal Ekonomi Pembangunan: Universitas Udayana. Vol 1: No 1: 1-60.

Badan Pusat Statistik. (2020). Indeks Pembangunan Manusia Tahun 2020. Jakarta: Badan Pusat Statistik.

Basuki, Agus Tri dan Nano Prawoto. (2015). Analisis Regresi dalam Penelitian Ekonomi dan Bisnis. Depok: Rajagrafindo Persada

Chatterjee, S. and J. S. Simonoff. (2013). Handbook of Regression Analysis. New Jersey: John Wiley \& Sons, Inc.

Dai, Sri Indriyani S. dan Sulila, Ismet. (2020). Purchase Power and Consumption Pattern Change of Society (Analysis of 34 Panel Data in Indonesia). Journal of Economics and Sustainable Development. Vol 11: No 2.

Gilarso, T. (2004). Pengantar Ilmu Ekonomi Makro. Yogyakarta: Kanisius.

Hernaningsih, Fery. (2018). Pengaruh Kestabilan Inflasi dan Ketimpangan Pendapatan Terhadap Daya Beli Masyarakat. Jurnal Ilmiah M-Progress. Vol 8: No 2.

Montgomery, C. Douglas, Elizabeth A. Peck and G. Geoffrey Vining. (2012). Introduction to Linear Regression Analysis Fifth Edition. New Jersey: John Wiley \& Sons, Inc.

Neter, John, William Wasserman and Michael H. Kutner (1983). Applied Linear Regression. Homewood: Richard D. Irwin, Inc.

Pramana S, Yordani R, Kurniawan R, Yuniarto B. (2017). Dasar-Dasar Statistika Dengan Software R: Konsep dan Aplikasi. Bogor: In Media.

Sayuti, Rosiady H. dan Hidayati, Siti Aisyah. (2020). Dampak Pandemi Covid-19 Terhadap Ekonomi Masyarakat di Nusa Tenggara Barat. RESIPROKAL: Jurnal Riset Sosiologi Preogresif Aktual. Vol 02: No 2.

Yuniati, Musniasih dan Amini, Rohmiati. (2020). Analisis Dampak Covid-19 Terhadap Daya Beli Masyarakat NTB. Mpu Procuratio: Jurnal Penelitian Manajemen. Volume 2: No 2.

Yusuf, Ayus Ahmad dan Nurmalah, Sinta. (2016). Pengaruh Pendapatan Perkapita, Investasi, dan Belanja Pemerintah terhadap Daya Beli Masyarakat di Wilayah III Cirebon Tahun 2010-2014. Al Amwal. Vol 8: No 1: hlm. 257.

Zarkasi. (2014). Pengaruh Pengangguran Terhadap Daya Beli Masyarakat Kalbar. Jurnal Khatulistiwa Journal of Islamic Studies. Vol 4: No 1. 